\title{
若年健常者と内側型変形性膝関節症症例の下肢形態の相違
}

九州労災病院整形外科
長 嶺 隆 二
九州大学整形外科
畑 中
中 俊

\section{Difference of Anatomic Configuration of Lower Extremity Between Normal Young Subjects and Patients with Medial Femorotibial Osteoarthritis}

\author{
Ryuji Nagamine \\ Department of Orthopaedic Surgery, \\ Kyushu Rosai Hospital \\ Toshiyuki Hatanaka, Hiromasa Miura, Ken Urabe, \\ Shuichi Matsuda, and Yukihide Iwamoto \\ Department of Orthopaedic Surgery, \\ Graduate School of Medical Science, Kyushu University
}

\begin{abstract}
In order to clarify characteristics of anatomic configuration of the lower extermity in patients with medial femorotibial osteoarthritis (OA), nine parameters were measured on anteroposterior radiographs of the lower extremities in the supine position in 135 Japanese female patients with OA and in 43 normal young female subjects. The results showed that the characteristics of the lower extermities in knees with OA are bowing of the femoral shaft and proximal tibia vara, with lateral off set of the tibial shaft with respect to the center of the tibial plateau. The length of the tibia was also significantly shorter in patients with OA compared with that in young normal subjects.

In younge subjects, four subjects $(9 \%)$ had varus deformity, which was thought to be a risk factor of medial OA. Prophyractic treatments may be necessary in oder to prevent medial $\mathrm{OA}$ in such subject.
\end{abstract}

Key words : Japanese (日本人), knee (膝), osteoarthirtis (変形性関節症), orthoradiograph (オルトラジオグラフ), anatomic variation（解剖学的バリエーション）

$$
\text { はじめに }
$$

日本人の変形性膝関節症（以下，OA）症例の中で, 内反型は $93 \%$ を占める ${ }^{3)}$. しかし, どのような解剖学 的特徴によって, 内反滕になっているのかを検討した
報告は少ない. 本研究の目的は, 内側型 $\mathrm{OA}$ 症例の 下肢の形態を若年健常者と比較し，その特徴を明らか にすることである。 さらに，内側型 OA の予防法に 関しても検討を加えた. 


\section{対象と方法}

内側型 OA 症例 135 例を対象とした。全例女性で あり，平均年齢は 70 歳（50 89 歳）である。若年健 常者は, 本研究の主旨を理解し, 協力を申し出た, 下 肢の痛みや疾患の既往がない, 21 歳の女性 43 名を対 象とした。

各症例において，卧位における，いわゆる orthoradiograph を撮影した ${ }^{6)}$. 最も留意した点と して，膝蓋骨を正面に向けた膝正面像での orthoradiographを撮影した点である.

各 orthoradigraphにおいて, 以下に示す, 合計 9 個の指標を計測した，全体像より，大腿骨長（骨頭か ら顆間窩までの距離), 脛骨長（近位関節面から遠位 関節面までの距離）と大腿骨長・脛骨長比，および膝 外側角を計測した（図 1 )。大腿骨においては，大腿 骨弯曲角（近位および遠位骨幹中心線のなす角）およ び大腿骨角（遠位骨幹中心線と関節面のなす外側の角）
を計測した（図 2 )。脛骨においては，脛骨角（近位 骨幹中心線と関節面のなす外側の角), 脛骨プラトー 偏位角（近位骨幹中心線と, 脛骨中点からプラトー中 心へ引いた線のなす角）および脛骨弯曲角（近位およ び遠位骨幹中心線のなす角）を計測した（図 3 ）。9 個の指標を若年健常者と OA 症例で比較検討した。

\section{結果}

各指標の結果を表 1 に示す。大腿骨長はほぼ一致し たが, 脛骨長は若年健常者で有意に長かった。膝外側 角, 大腿骨弯曲角, 脛骨角および脛骨プラトー偏位角 にも大きな有意差を認めた。大腿骨角および脛骨弯曲 角には有意差を認めなかった。

以上をまとめると, 内側型 OA 症例の下肢形態の 特徵は, 大腿骨は骨幹部で外側へ弯曲し, 脛骨は短く, 近位骨幹端にて内側入弯曲し, 従って, 関節面も内側 へ偏位していることである。

一方, 若年健常者において, 内反変形の頻度を検討

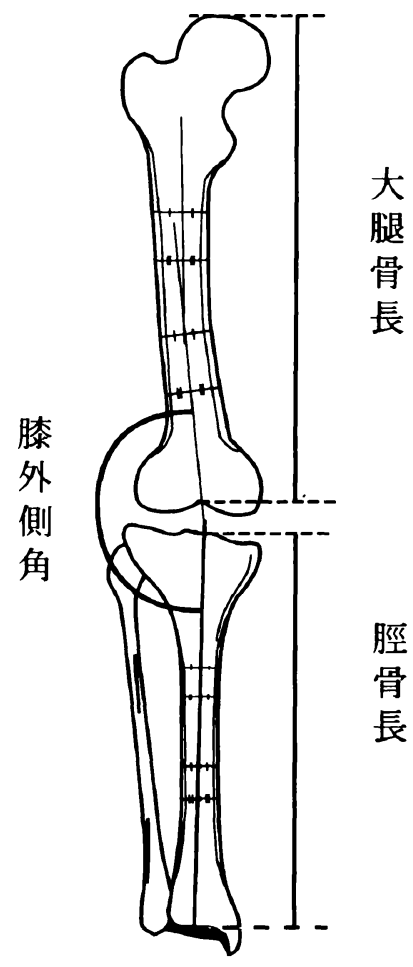

図 1 orthoradiographにおいて，下肢全体からは， 大腿骨長, 脛骨長および大腿骨長・脛骨長比を 計測，また，膝外側角も計測した。
大
腿
骨
長

脛
骨
長 


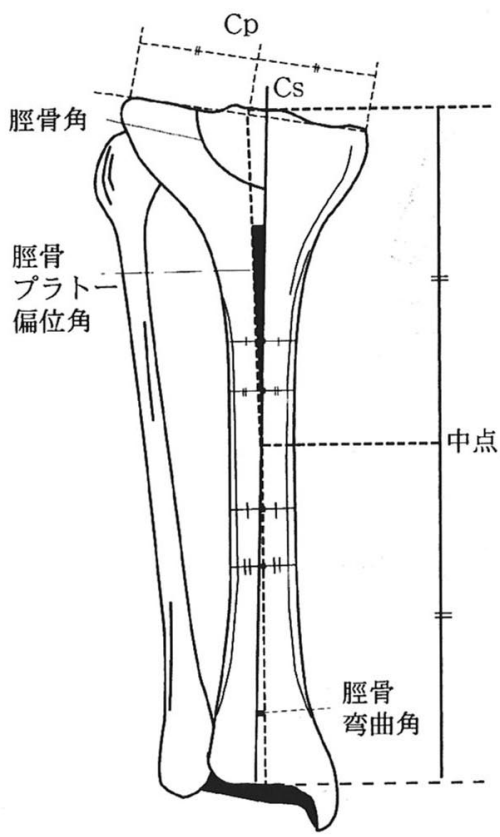

表 1

\begin{tabular}{lccc}
\hline \hline & OA & 健常者 & $\mathrm{p}$ \\
\hline 大腿骨長 $(\mathrm{mm})$ & 387 & 391 & $\mathrm{~ns}$ \\
脛骨長 $(\mathrm{mm})$ & 307 & 325 & $<.0001$ \\
大腿骨長脛骨長比 & 1.26 & 1.20 & $<.0001$ \\
膝外側角 $\left(^{\circ}\right)$ & 181 & 176 & $<.0001$ \\
大腿骨弯曲角 $\left(^{\circ}\right)$ & 2.3 & -2.4 & $<.0001$ \\
大腿骨角 $\left(^{\circ}\right)$ & 82.1 & 81.3 & $\mathrm{~ns}$ \\
脛骨角 $\left(^{\circ}\right)$ & & & \\
プラトー偏位角 $\left(^{\circ}\right)$ & 2.0 & 0.8 & $<.0001$ \\
脛骨弯曲角 $\left(^{\circ}\right)$ & 0.1 & 0.8 & $\mathrm{~ns}$ \\
\hline
\end{tabular}

図 3 脛骨においては, 脛骨角（脛骨近位骨幹中心線 とプラトーのなす角), 脛骨弯曲角 (近位と遠 位骨右中心線のなす角）および脛骨プラトー偏 位（プラトーの中心である $\mathrm{Cp}$ から脛骨中点へ 引いた線と近位骨幹中心線のなす角）を計測し た.なお，Csは骨幹中心線の延長線とプラトー との交点を示す.
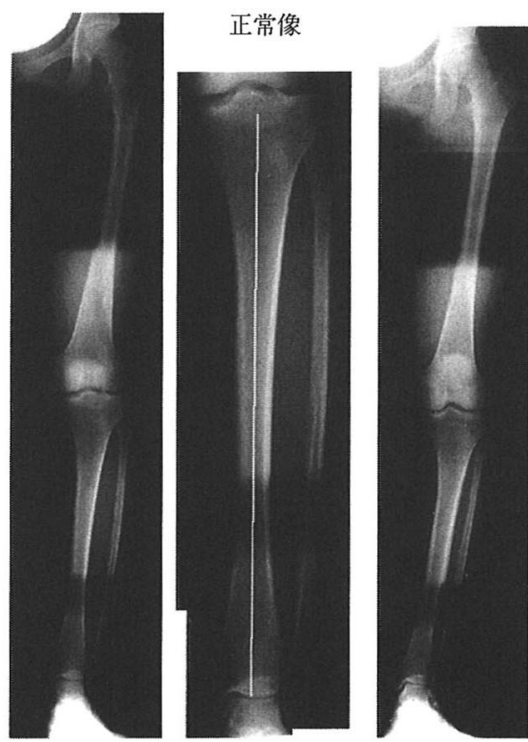

内反膝

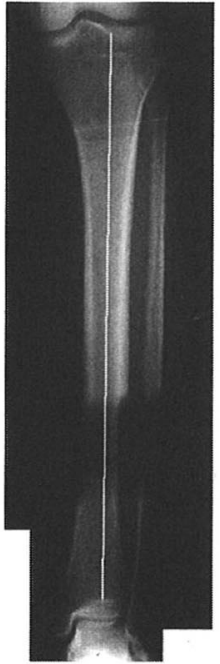

図 4 若年健常者においても，約 $4 \%$ に内反変形が強い症例 を認めた。これらの症例は内側型変形性膝関節症の危険 因子を持っていると考えられる。 
したが，平均値より $2 \mathrm{SD}$ (標準偏差）以上の值を示 したのは, FTA で（180 度以上），4例 $9 \%$, 脛骨角 で (98 度以上), 1 例 $3 \%$, 脛骨プラトー偏位角で（2 度以上)，4例 $9 \%$ であった。これらの症例は，内側 型 OAに進行するリスクを有していると考えられる.

\section{考察}

内側型 OA の進行に伴い大腿骨が外側へ弯曲する ことは報告されており，本現象は，OA 発症の一要因 でもある゙).しかし，脛骨においては，発症以前より 近位骨幹端部で内反しており，脛骨の形態が日本人に おける内側型 OA 症例が多い原因であろう.

内反変形では，小児期には一般的に認められる現象 であり, 通常, 成長と共に, 内反変形は消失してい (1)5). しかし, 本研究より, 脛骨の長さが短く, 近位 骨幹端部での内反が認められたことより，成長期にお ける近位骨幹端（特に内側部）での成長障害が起こっ ている可能性も否定できない. 日系ハワイ人には，内 反変形が日本在住日本人と比較して少ないことも報告 されており，食事や生活様式により，脛骨の成長は影 響を受ける2). 脛骨の内反変形に伴い㯟の内反が生じ, 加齢に伴い大腿骨の外側への弯曲が進行して，さらに 内反変形が進行し, 内側型 $\mathrm{OA}$ が発症していくと考 えられる。

それでは，その予防法に関して重要な点としては， リスクのある症例を発見することが第一と考える．本 研究の結果では, 約 4 \%にリスクのある健常者を認め た.このような症例では, 図 4 に示す如く，20歳代 にて内反変形を認める。このような症例では, 内側型 OA に進行する可能性が高いことを説明し，大腿骨外 側弯曲などの変形が進行しないように, 経過観察を行
い, 適宜, 体重のコントロール, 歩行方法の指導, 大 腿四頭筋の訓練の指導，早目の足低板装着などを行う ことが重要と考える。

また，OAに進行し，人工膝関節置換術を行う場合 は，これらの解剖学的バリエーションを考慮に入れて， 使用システムの選択, 手術手技の変更を行うことが重 要である.

結語

内側型変形性膝関節症症例においては, 脛骨近位骨 幹端の内反変形, およびそれに伴う脛骨関節面の内側 への偏位が特徴的である.

\section{参 考 文 献}

1）天児民和：膝関節 下肢の弯曲について. 神中整形外 科, 南光堂, p.1115-1124, 1975

2) Aoyagi, K., Ross, P. D., Huang, C., et al.: Prevalence of joint pain is higher among women in rural Japan than urban. - Japanese-American women in Hawaii. Ann Rheum Dis, 58 : 315-319, 1999.

3）腰野富久：変形性関節症とくに膝における病態と治療. リウマチ, 34:185-186, 1994.

4) Kurosaka, M., Hashimoto, M., Yoshiya, S., et al.: Radiographic assessment of static lower limb alignment of varus osteoarthritic knees. Orthopaedic Research Society. 1994; Transaction of the 40th Annual Meeting; 1994 Feb 21-24; New Orleans. Orthopaedic Research Society, $1994: 675$.

5）長嶺隆二, 三浦裕正, 占部 憲, 他: 学童期の下肢ア ライメント異常と膝蓋大腿関節疾患. 関節外科, $17: 72-$ $77,1998$.

6) Nagamine, R., Miura, H., Bravo, C. V., et al.: Anatomic variations should be considered in total knee arthroplasty. J Orthop Sci., 5 : 232-237, 2000. 